\title{
SDÍLENÁ EKONOMIKA V ROZHODOVACÍ PRAXI SDEU A ČESKÝCH SOUDŮ
}

\author{
DAVID ROTREKL ${ }^{1}$
}

\section{1. ÚVOD}

V květnu a červenci vydal generální advokát při Soudním dvoru Evropské unie stanoviska, týkající se společnosti Uber, a kromě toho české soudy $\mathrm{v}$ posledních měsících vydaly velké množství rozhodnutí k této problematice. Je tedy nepochybné, že se právě rozhoduje o dalším fungování společnosti Uber, možná dokonce celé sdílené ekonomiky, nejen v České republice, ale v celé Evropské unii.

\section{JAK SLUŽBA SPOLEČNOSTI UBER FUNGUJE?}

Společnost Uber mezi sebou propojuje vlastníky automobilů, kteří se chtějí ve svém volném čase přivydělat a osoby, které potřebují přepravu. Zákazník i řidič spolu komunikují prostřednictvím aplikace, kterou mají staženou ve svém smartphonu nebo jiném podobném zařízení. Zákazník zadá místo, odkud chce jet (nebo nechá zaměřit svou polohu pomocí GPS) a aplikace upozorní nejbližšího řidiče na zákazníka. Řidič se musí během 15 vteřin rozhodnout, zda zákazníka sveze anebo nikoli. V době rozhodnutí řidič nevidí, kam chce zákazník jet, aby si nemohl vybírat zakázky podle toho, jak jsou lukrativní, tedy podle toho, jak daleko chce zákazník svézt. V případě, že řidič zákazníka odmítne, upozorní aplikace druhého nejbližšího řidiče, a tak celý proces pokračuje, než aplikace nenajde řidiče, který by zákazníka svezl. Jakmile řidič dorazí na místo, kde se nachází zákazník, upozorní

Student 4. ročníku Právnické fakulty Masarykovy univerzity. Kontaktní e-mail: 433533@mail.muni.cz. 
aplikace zákazníka, že na něj řidič čeká. Zákazník zároveň obdrží informace o vozidle, kterým pojede a řidiči, aby věděl, do jakého auta nastoupit. Po absolvování jízdy se neplatí hotově, ale pomocí aplikace ve smartphonu. Cena se přitom skládá z nástupní sazby, sazby za ujeté kilometry a sazby za čas strávený přepravou. Tím, že platba neprobíhá $\mathrm{v}$ hotovosti, ale zprostředkovává ji společnost Uber, nemůže řidič cestu předražovat. ${ }^{2}$

\section{SOUDNÍ SPORY SPOLEČNOSTI UBER}

Proti společnosti Uber vystupují v jednotlivých evropských zemích především taxikáři, kterým společnost Uber přebírá zákazníky. Taxikáři vystupují proti společnosti Uber nejen před soudy, ale organizují demonstrace a někdy vystupují jednotlivě proti řidičům společnosti Uber. V poslední době probíhaly spory mezi řidiči klasických taxislužeb a řidiči společnosti Uber především na pražském letišti Václava Havla. Taxikáři dokonce v souvislosti se zákazem činnosti řidičům společnosti Uberu dali ultimátum pražské primátorce. Ta má podle nich činnost společnosti Uber na území města Prahy zakázat, v opačném případě, pak řidiči taxislužeb vyhrožují zablokováním pražských ulic. ${ }^{3}$

Spor před soudy se dostal až k Soudnímu dvoru Evropské unie, který se sice ještě $k$ věci vyjádřit nestihl. Nicméně generální advokát Maciej Szpunar při Soudním dvoru Evropské unie, již stihl dne 11. května 2017 vydat své stanovisko ve věci Asociación Profesional Elite Taxi (dále jen žalobce) proti Uber Systems Spain SL (dále jen žalovaný).

Vše začalo, když dne 29. 10. 2014 podal žalobce žalobu, kterou se domáhal, aby byl žalovaný shledán vinným z porušování právních předpisů, nekalosoutěžního jednání, a aby mu bylo nařízeno ukončení tohoto jednání. Žalovaný se bránil tím, že provozuje službu informační společnosti ve smyslu směrnice č. 2000/31 o některých aspektech služeb informační společnosti, zejména elektronického obchodu, na vnitřním trhu (dále jen

Uber [online]. Uber B.V. [cit. 20. 9. 2017]. Dostupné z: https://help.uber.com/ cs_CZ/h/67f41961-e0aa-4670-af32-58be02c7c492

3 Heller, Jakub. Taxikáři dali Krnáčové ultimátum kvůli Uberu, hrozí blokádou In: Idnes.cz [online]. Mafra a.s., 2017. [cit. 19. 9. 2017]. Dostupné z: http://zpravy.idnes.cz/demonstracetaxikar-uber-protest-dlz-/domaci.aspx?c $=$ A170918_095826_domaci_nub 
směrnice o elektronickém obchodu) a v rámci Evropské unie může proto provozovat službu za hranicemi státu, kde je společnost usazena $\mathrm{v}$ rámci volného pohybu služeb ve smyslu směrnice 2006/123 o službách na vnitřním trhu. ${ }^{4}$

Španělský soud se obrátil na Soudní dvůr Evropské unie celkem se čtyřmi předběžnými otázkami. Obsahem těchto otázek je však především to, zda společnost Uber provozuje službu informační společnosti ve smyslu směrnice o elektronickém obchodu nebo službu v oblasti dopravy, a tedy se na ni dle článku 2 odst. 2 písm. d) směrnice č. 2006/123 o službách na vnitřním trhu nevztahuje a není tak možné využít volného pohybu služeb po Evropské unii. Otázkou tak je, zda společnost Uber pomocí své aplikace pro chytré telefony pouze propojuje nabídku s poptávkou v oblasti osobní dopravy, nebo zda osobní dopravu sama provozuje?

Směrnice o elektronickém obchodu sama o sobě neobsahuje definici služby informační společnosti, ale odkazuje na směrnici č. 1998/34 o postupu při poskytování informací v oblasti norem a technických předpisů. Tato směrnice obsahuje následující definici: „služba informační společnosti, tj. každá služba poskytovaná zpravidla za úplatu, na dálku, elektronicky a na individuální žádost př́jemce služeb. “5

Dle generálního advokáta při Soudním dvoru EU Macieje Szpunara se služba společnosti Uber skládá ze dvou částí, ze zprostředkování dopravy, které probíhá na dálku pomocí mobilní aplikace a poté následuje samotná doprava. Zatímco zprostředkování dopravy spadá pod výše uvedenou definici, následná doprava už nikoli, jedná se tedy o službu smíšenou. Smíšené služby však za určitých okolností také spadají pod rozsah směrnice o elektronickém obchodu, jelikož jinak by tato směrnice nemohla dosáhnout svého cíle, jímž je liberalizace trhu. Aby bylo možné uvedené služby pod roz-

4 Stanovisko generálního advokáta Marcieje Szpunara ze dne 11. 5. 2017, věc C-434/15 [cit. 16. 5. 2017] Dostupné z: http://eur-lex.europa.eu/legal-content/CS/TXT/?qid= 1494943061735\&uri = CELEX:62015CC0434

5 Čl. 1 odst. 2 směrnice Evropského parlamentu a Rady ze dne 20. 7. 1998, č. 1998/48/ES, kterou se mění směrnice 98/34/ES o postupu při poskytování informací v oblasti norem a technických předpisů. In: EUR-Lex [právní informační systém]. Úřad pro publikace Evropské unie. [cit. 21. 9. 2017]. Dostupné z: http://eur-lex.europa.eu/legal-content/CS/TXT/? qid $=1505989748852 \&$ uri $=$ CELEX:31998L0048 
sah této směrnice zahrnout, musí být obě částečná plnění na sobě ekonomicky nezávislá (např. zprostředkovatelé, pomáhající navázat obchodní vztahy). Pokud však elektronickou i neelektronickou část plnění poskytuje pouze jeden subjekt, je potřeba zjistit, které plnění má ekonomický význam. Aby šlo danou službu podřadit pod rozsah směrnice o elektronickém obchodu, musí být elektronická část plnění tou částí, která má ekonomický význam.

Společnost Uber kontroluje veškeré důležité prvky dopravy - cenu, prostřednictvím požadavků na řidiče a jejich vozidla bezpečnost dopravy, dostupnost dopravy ovlivňuje společnost Uber prostřednictvím motivování řidičů (v době vysoké poptávky po přepravě je služba dražší a řidiči mají vyšší zisk, $\mathrm{v}$ takovýchto chvílích navíc společnost Uber rozesílá řidičům SMS zprávy, aby začali přepravovat zákazníky) a společnost Uber může dokonce jednotlivé řidiče ze služby vyloučit (děje se tak, pokud mají nízké hodnocení od zákazníků).

Toto vede k závěru, „že činnost společnosti Uber spočívá $v$ jediném plnění tvořeném přepravou vozidlem nalezeným a objednaným pomocí aplikace pro chytré telefony a tato služba je z ekonomického hlediska poskytována společností Uber nebo jejím jménem “6 a jde tedy o službu v oblasti dopravy a nikoli službu informační společnosti.

K tomu, že službu poskytuje samotná společnost Uber, a nikoliv jednotliví řidiči společnosti Uber, dopěl také Anglický soud v pracovněprávních věcech. Ten ale zašel ještě dál, když konstatoval, že jelikož společnost Uber provozuje celou službu, tak jednotlivé řidiče společnosti Uber nemůžeme považovat za podnikatele, ale za zaměstnance společnosti Uber. Řidiči pak podle soudu jakožto zaměstnanci společnosti Uber mají nárok na minimální mzdu nebo náhradu mzdy v době dovolené.?

Stanovisko generálního advokáta Marcieje Szpunara ze dne 11. 5. 2017, věc C-434/15. [cit. 16. 5. 2017] Dostupné z: http://eur-lex.europa.eu/legal-content/CS/TXT/?qid = 1494943061735\&uri = CELEX:62015CC0434

7 Judgement of the Employment tribunal ze dne 28. 10. 2017, case number: 2202551/2015 \& Others. [15. 11. 2017]. Dostupné z: https://www.judiciary.gov.uk/judgments/mr-yaslam-mr-j-farrar-and-others-v-uber/ 
Generální advokát Maciej Szpunar při Soudním dvoru Evropské unie přednesl dne 4. července 2017 své stanovisko ve věci Uber France SAS, kterým navázal na své předchozí výše popsané stanovisko.

V původním řízení podal pan Nabil Bensal návrh na zahájení trestního ř́zení proti společnosti Uber France k trestnímu soudu v Lille, ve vztahu k mnoha skutkům, včetně organizace systému zprostředkování kontaktu mezi zákazníky a osobami, které vykonávají silniční dopravu za úplatu vozidly s méně než deseti místy za podmínek stanovených v článku L. 312413 zákona o dopravě.

Společnost Uber se hájila tím, že článek L.3124-13 zákona o dopravě nelze proti ní uplatnit, jelikož představuje technický předpis ve smyslu směrnice Evropského parlamentu a rady č. 1998/34, o postupu při poskytování informací v oblasti norem a technických předpisů, který nebyl oznámen Evropské komisi ve smyslu čl. 8 odst. 1 této směrnice.

Francouzský soud za těchto okolností přerušil řízení a položil Soudnímu dvoru EU dvě předběžné otázky. První otázkou bylo, zda je článek L.312413 technickým předpisem ve smyslu uvedené směrnice? Druhou předběžnou otázkou byla otázka, zda $\mathrm{v}$ případě, že tento článek je technickým předpisem, jaká je sankce za neoznámení technického předpisu Evropské komisi?

Na první předběžnou otázku generální advokát odpovídá tak, že dotčený článek není technickým předpisem, a že technickým předpisem nemůže být vnitrostátní ustanovení jen proto, že ukládá sankci za zprostředkování protiprávních činností, a že ke zprostředkování dochází pravděpodobně elektronickou cestou.

Pro jistotu odpovídá generální advokát i na druhou předběžnou otázku, a to tak, že podle ustálené judikatury Soudního dvora EU neoznámení technického předpisu Komisi zakládá vadu řízení při přijímání těchto předpisů a vede $\mathrm{k}$ nepoužitelnosti těchto předpisů vůči jednotlivcům (viz např. bod 67 rozsudku Soudního dvora EU ze dne 4. 2. 2016 ve věci C 336/14, nebo bod 48 rozsudku Soudního dvora EU ze dne 10. 7. 2014 ve věci C 
307/13). ${ }^{8}$ Ve Francii je proti společnosti Uber vedeno trestní řízení, a proto by $\mathrm{v}$ případě, že by se jednalo o technický předpis, nemohl být tento předpis vưči společnosti Uber uplatněn.

\section{JAK ŘEŠÍ SLUŽBU SPOLEČNOSTI UBER ČESKÉ SOUDY?}

Ve věci společnosti Uber již proběhla řízení i před českými soudy, a doposud byla vydána dvě předběžná opatření proti společnosti Uber, jedno Městským soudem v Praze a jedno Krajským soudem v Brně, a také několik dalších rozhodnutí. Usnesení Městského soudu v Praze vydané v řízení pod sp. zn. 2 Nc 1052/2016 umožnilo společnosti Uber nadále provozovat svou službu. Zamítnutí tohoto předběžného opatření bylo odůvodněno tak, že právní institut předběžného opatření slouží k zabránění nově nastalé protiprávní situaci, proti které je nutné co nejrychleji zasáhnout, a že v době podání návrhu na podání předběžného opatření fungovala společnost Uber v Praze již dva roky. Předběžné opatření tedy nemohlo zabránit nově nastalé protiprávní situaci, protože pokud protiprávní situace trvala, tak již dlouhodobě. ${ }^{9}$

Možná právě z tohoto předběžného opatření se poučili taxikáři v Brně a úspěšně podali návrh na vydání předběžného opatření u Krajského soudu v Brně č. j. 18 Nc 9/2017-46, které službu společnosti Uber v Brně zakázalo ne dlouho poté, co společnost Uber v Brně začala fungovat. Předběžné opatření Krajského soudu v Brně v odůvodnění pouze konstatuje, že žalobce osvědčil rozhodné skutečnosti a odkazuje na § 169 odst. 2 zákona č. 99/1963 Sb., občanský soudní řád, ve znění pozdějších předpisů, dle kterého předběžné opatření, kterému soud vyhověl a nikdo mu neodporoval nemusí obsahovat podrobnější odůvodnění. ${ }^{10} \mathrm{Z}$ důvodu absence odůvodnění označil Vrchní soud v Olomouci toto předběžní opatření za nepřezkou-

\footnotetext{
8 Stanovisko generálního advokáta Marcieje Szpunara ze dne 4. 7. 2017, věc C-320/16. [cit. 29. 9. 2017] Dostupné z: http://eur-lex.europa.eu/legal-content/CS/TXT/?qid= 1506713531770\&uri = CELEX:62016CC0320

9 Usnesení Městského soudu v Praze ze dne 21. 7. 2017 č. j. 2 Nc 1052/2016-59. [cit. 27. 9. 2017]. Dostupné z: https://is.muni.cz/www/433533/Uber_-predbezne_opatreni_Praha.pdf

10 Usnesení Krajského soudu v Brně ze dne 7. 4. 2017, č. j. 18 Nc 9/2017-46. [cit. 27. 9. 2017]. Dostupné z: http://www.ceskatelevize.cz/ct24/sites/default/files/19394921936236-1921296-1900698-predbezne_opatreni_uber_b.v_0_0_0.pdf
} 
matelné a předběžné opatření zrušil usnesením č. j. 7 Cmo 137/2017-341 a odkázal přitom na několik nálezů Ústavního soudu (např. III. ÚS 346/09). ${ }^{11}$ Krajský soud v Brně, následně předběžné opatření potvrdil usnesením č. j. 18 Nc 9/2017-377 a obhajoval neodůvodnění předběžného opatření odkazem na nález Ústavního soudu ÚS 2463/2014. ${ }^{12}$ Vrchní soud v Olomouci vydal dne 26. 10. 2017 ve věci konečné usnesení č. j. 7 Cmo 185/2017-507, kterým změnil usnesení Krajského soudu v Brně tak, že společnost Uber může v Brně znovu začít provozovat své služby. Dle Vrchního soudu v Olomouci nebyla tvrzení žalobce v souladu s jím navrhovaným petitem, a navíc nešlo o vykonatelný petit. (Žalobce se domáhal, aby se žalovaný zdržel provozování a zprostředkování taxislužby.) Vrchní soud v Olomouci však dospěl k závěru, že z popisu žalovaného vyplývá, že neprovozuje taxislužbu, ale "jinou službu v oblasti dopravy", a proto mu nelze uložit zákaz provozování či zprostř̌edkování taxislužby. $V$ závěru rozhodnutí pak Vrchní soud v Olomouci uvádí, že otázkou, zda se žalovaný dopouští nekalé soutěže se bude soud zabývat až v řízení ve věci samé. ${ }^{13}$

Z mého pohledu je rozhodnutí Vrchního soudu v Olomouci překvapivé, jelikož zákon o silniční dopravě s pojmem "jiná služba v oblasti dopravy" nepracuje. Je také škoda, že Vrchní soud v Olomouci více nerozvedl, proč se domnívá, že společnost Uber neprovozuje ani nezprostředkovává taxislužbu a uvedl jen, že toto vyplývá z popisu žalovaného a odkazuje na předchozí strany svého usnesení. Žalobce pak může jen hádat, čím konkrétně žalovaný Vrchní soud v Olomouci o tomto přesvědčil. Nemůže takovéto odůvodnění vést $\mathrm{k}$ nepřezkoumatelnosti rozhodnutí, pro kterou zrušil Vrchní soud v Olomouci první předběžné opatření ve věci společnosti Uber č. j. 18 Nc 9/2017-46, Krajského soudu v Brně?

11 Usnesení Vrchního soudu v Olomouci ze dne 22. 6. 2017, č. j. 7 Cmo 137/2017-341. [cit. 27. 9. 2017]. Dostupné z: https://is.muni.cz/www/433533/Uber__predbezne_opatreni_Brno_-_Vrchni_soud_v_Olomouci.pdf

12 Usnesení Krajského soudu v Brně ze dne 17. 7. 2017, č. j. 18 NC 9/2017-377. [cit. 27. 9. 2017]. Dostupné z: http://www.ceskatelevize.cz/ct24/sites/default/files/1951603487574200_0_18nc_9_2017_48.pdf

13 Usnesení Vrchního soudu v Olomouci ze dne 27. 9. 2017, č. j. 7 Cmo 185/2017-507. [cit. 3. 11. 2017]. Dostupné z: https://is.muni.cz/www/433533/7Cmo_185-2017.pdf 
Usnesení Vrchního soudu v Olomouci č. j. 7 Cmo 185/2017-507, je zajímavé srovnat s rozsudkem Nejvyššího správního soudu ze dne 31. 10. 2017, č. j. 9 As 291/2016-131. Tímto rozsudkem totiž Nejvyšší správní soud zrušil rozsudek Městského soudu v Praze ze dne 26. 10. 2016, č. j. 1 A 96/2015-38. V řízení u Městského soudu v Praze se jeden z řidičů společnosti Uber bránil proti udělené pokutě Magistrátem hlavního města Prahy. Městský soud v Praze zrušil udělenou pokutu, jelikož dle něj sdílená přeprava není právním řádem České republiky regulována, a proto pokutovaný řidič neměl možnost zjistit, že porušuje právní předpisy. Nejvyšší správní soud ve věci konstatoval: „přeprava osob uskutečněná řidiči, kteří používají aplikaci UberPop, se neodehrává v právním vakuu. Jakkoliv využívají moderní technologická řešení a alternativní ekonomické formy, neznamená to automaticky, že jejich činnost nepodléhá žádným pravidlưm.“ Dle Nejvyššího správního soudu, měl Městský soud v Praze posoudit, zda přeprava poskytovaná řidiči společnosti UberPop nenaplňuje znaky nějakého právního institutu, který současný právní řád zná. ${ }^{14}$

Zatímco Vrchní soud v Olomouci dospěl k závěru, že společnost Uber neprovozuje taxislužbu, ale „jinou službu v oblasti dopravy“, Nejvyšší správní soud se ptá Městského soudu v Praze, zda sdílená přeprava provozovaná společností Uber nelze podřadit pod právní institutu, který český právní řád zná. Nejvyšší správní soud se tak nenápadně ptá, zda společnost Uber neprovozuje taxislužbu. Rozsudek Nejvyššího správního soudu má blíže ke stanovisku generálního advokáta ve věci C-434/15, který ve svém stanovisku konstatoval: „Řidiči totiž v rámci této platformy nabízejí cestujícím prepravu do jimi zvoleného cíle, a tudíž jsou odměňováni částkami vysoce prevyšujícími pouhou náhradu vynaložených nákladů. Jedná se tedy o klasickou přepravní službu. To, zda patři do „sdílené ekonomiky“, nemá žádný dopad na její kvalifikaci z pohledu platného práva. “15 Dále v textu pak bude vysvětleno,

\footnotetext{
14 Rozsudek Nejvyššího správního soudu ze dne 31. 10. 2017, č. j. 9 As 291/2016-131. [cit. 13. 11. 2017] Dostupný z: http://www.nssoud.cz/files/SOUDNI_VYKON/ 2016/0291_9As_1600136_20171101151509_prevedeno.pdf

15 Odstavec 42, Stanoviska generálního advokáta Marcieje Szpunara ze dne 11. 5. 2017, věc C-434/15. [cit. 11. 11. 2017] Dostupné z: http://eur-lex.europa.eu/legal-content/ CS/TXT/?qid = 1494943061735\&uri = CELEX:62015CC0434
} 
proč se právní úprava taxislužby na službu společnosti Uber opravdu vztahuje.

Další předběžná opatření, vydaná českými soudy sice nesměřují přímo proti společnosti Uber, ale týkají se sdílené dopravy. Prvním z nich je předběžné opatření č. j. 2 Nc 1041/2017-86 vydané Městským soudem v Praze proti společnosti Taxify, která je konkurentem společnosti Uber. Společnost Taxify funguje na podobném principu jako společnost Uber, a proto se $\mathrm{k}$ tomuto předběžnému opatření dá přistupovat stejně, jako by bylo vydáno proti společnosti Uber. Toto předběžné opatření zakázalo fungování společnosti Taxify na území města Prahy.

Dle odůvodnění předběžného opatření žalobce exekutorskými zápisy osvědčil, že žalobce provozuje taxislužbu obdobným způsobem jako společnost Uber (auta nejsou označená jako vozidla taxislužby, cena není určována pomocí taxametru a řidiči nemusejí být držiteli oprávnění řidiče taxislužby). $\mathrm{V}$ odůvodnění je dále uvedeno, že společnost Taxify provozuje taxislužbu na území města Prahy již od srpna roku 2015, ovšem je zde tvrzeno, že společnost zpočátku veřejnoprávní úpravu taxislužeb dodržovala a až v průběhu svého provozu v Praze tuto úpravu dodržovat přestala. Tato skutečnost však není žádným způsobem $v$ předběžném opatření osvědčena a soud $\mathrm{k}$ ní tak neměl při rozhodování přihlížet. $\mathrm{V}$ rámci zachování právní jistoty pak měl soud návrh na vydání předběžného opatření zamítnout, stejně jako to udělal svým dřivějším usnesením s návrhem na vydání předběžného opatření, který směřoval proti společnosti Uber. ${ }^{16}$ Předběžné opatření zrušil již Vrchní soud v Praze usnesením č. j. 3 Cmo 147/2017-164, avšak ne $\mathrm{z}$ výše uvedených důvodů, ale opět mu vadila především absence odůvodnění předběžného opatření. Ke shora uvedeným problémům předběžného opatření však Vrchní soud v Praze uvedl, že by se $\mathrm{s}$ nimi také měl soud prvního stupně $\mathrm{v}$ dalším rozhodnutí vypořádat. ${ }^{17} \mathrm{~S}$ výše uvedenými připomínkami se Městský soud v Praze nedokázal vypořá-

\footnotetext{
16 Usnesení Městského soudu v Praze ze dne 26. 5. 2017, č. j. 2 Nc 1041/2017-86. [cit. 27. 9. 2017]. Dostupné z: https://is.muni.cz/auth/www/433533/2_Nc_1041_2017_86_Mestsky _soud_v_Praze.pdf

17 Usnesení Vrchního soudu v Praze ze dne 31. 7. 2017, č. j. 3 Cmo 147/2017-164. [cit. 27. 9. 2017]. Dostupné z: http://www.taxi-praha.cz/wp-content/uploads/2017/09/taxify-zat \%C3\%ADm-v\%C3\%ADt\%C4\%9Bz\%C3\%AD.pdf
} 
dat, a proto nakonec zamítl návrh na vydání předběžného opatření proti společnosti Taxify usnesením č. j. 2 Nc 1041/2017-179. ${ }^{18}$

Dalším relevantním předběžným opatření je usnesení Krajského soudu v Brně ze dne 20. 3. 2017, č. j. 18 Nc 6/2017-26. Toto předběžné opatření zakázalo činnost na území města Brna Jakubu Dümlerovi, jednomu z řidičů společnosti Uber. ${ }^{19}$ Pro nedostatek odůvodnění toto předběžné opatření zrušil Vrchní soud v Olomouci usnesením ze dne 25. 5. 2017, č. j. 7 Cmo 113/2017-70. ${ }^{20}$ Krajský soud v Brně následně opět vydal dne 17. 7. 2017 předběžné opatření proti řidiči společnosti Uber č. j.18 Nc 6/2017-99 a o věci budu znovu rozhodovat i Vrchní soud v Olomouci. ${ }^{21}$

\section{JAKÝ DOPAD MÁ APLIKACE ZÁVĚRU GENERÁLNÍHO ADVOKÁTA NA ČINNOST UBERU V ČESKÉ REPUBLICE?}

I když se generální advokát při soudním dvoru EU zabývá jinou otázkou, než kterou se dosud zabývaly české soudy ve věci společnosti Uber, může jeho argumentace a případně následné shodné rozhodnutí Soudního dvora EU mít vliv, také na rozhodování českých soudů.

Generální advokát při soudním dvoru EU ve svém stanovisku ze dne 11. května 2017 vylučuje aplikaci směrnice č. 2006/123 o službách na vnitřním trhu na činnost společnosti Uber. Pokud shodně rozhodne také Soudní dvůr EU (což ve zbývající části textu předpokládám), společnost Uber přijde o obranu, kterou dosud uplatňovala ve sporech, které proti ní byly vedeny v zahraničí. Dalo se očekávat, že podobně se bude společnost Uber bránit také $\mathrm{v}$ České republice, kde ve věci společnosti Uber soudy dosud vydávaly pouze předběžná opatření. Soudy tedy rozhodovaly pouze na

18 Usnesení Městského soudu v Praze ze dne 1. 9. 2017 č. j. 2 Nc 1041/2017-179- [cit. 27. 11. 2017]. Dostupné z: https://is.muni.cz/auth/www/433533/2Nc_1041_2017_179.pdf?studi$\mathrm{um}=681471$

19 Usnesení Krajského soudu v Brně ze dne 20. 3. 2017, č. j. 18 Nc 6/2017-26. [cit. 27. 9. 2017]. Dostupné z: https://is.muni.cz/www/433533/18Nc_6_2017_usneseni_KS_Brno_1.pdf

20 Usnesení Vrchního soudu v Olomouci ze dne 25. 5. 2017, č. j. 7 Cmo 113/2017-70. [cit. 27. 9. 2017]. Dostupné z: https://is.muni.cz/www/433533/7Cmo_113_2017_70_usneseni _Vrchni_soud_v_Olomouci.pdf

${ }^{21}$ Usnesení Krajského soudu v Brně ze dne 17. 7. 2017, č. j. 18 Nc 6/2017-99. [cit. 27. 9. 2017]. Dostupné z: https://is.muni.cz/www/433533/18Nc_6_2017_36_usneseni_KS _Brno_2.pdf 
základě skutečností, které osvědčil žalobce a žalovaná společnost Uber napadala předběžná opatření především z procesních důvodů. Nyní však již probíhá klasické soudní řízení ve věci společnosti Uber v Praze pod sp. zn. $15 \mathrm{Cm}$ 25/2016 a v Brně pod sp. zn. $18 \mathrm{Cm}$ 181/2017. V rámci těchto řízení je však zatím nutné počkat, na zjištění, jakou obranu společnost Uber zvolí.

Ze stanoviska generálního advokáta vyplývá, že společnost Uber je službou v oblasti dopravy, a proto není možné aplikovat směrnici 2006/123 o službách na vnitřním trhu v souladu s článkem 2 odst. 2 písm. d) této směrnice. Ten totiž vylučuje použití směrnice na služby v oblasti dopravy. ${ }^{22}$ I když generální advokát nekonstatuje, zda je služba společnosti Uber taxislužbou nebo ne. Myslím si, že při neaplikování této směrnice se dovodí, že společnost Uber je taxislužbou. Společnost Uber se totiž nebude moct bránit poukazem na směrnici o službách na vnitřním trhu, což dosud činilo tuto otázku spornou a bude se postupovat výhradně podle vnitrostátního práva. Definice taxislužby je $\mathrm{v}$ českém právu obsažena v $\S 2$ odst. 9 zákona č. 111/1994 Sb., o silniční dopravě, ve znění pozdějších předpisů (dále jen "zákon o silniční dopravě"), podle které je taxislužbou osobní doprava, pro cizí potřeby, maximálně pro 9 osob a následuje negativní vymezení taxislužby. Řidiči společnosti Uber přepravují osoby v osobních automobilech a jde tedy o osobní přepravu maximálně pro 9 osob. Zákon o silniční dopravě v $\S 2$ odst. 3 také uvádí, že o dopravu pro cizí potřeby se jedná, pokud mezi provozovatelem silniční dopravy a přepravovanou osobou vznikne závazkový vztah, jehož předmětem je přeprava osob, zviřat nebo věcí.

Podle mě je tedy společnost Uber taxislužbou, a proto by měla plnit povinnosti, které taxislužbám ukládá zákon o silniční dopravě a další právní předpisy. Např́klad mít auta označená žlutou svítilnou „TAXI“, vybavená taxametrem a mít na nich uvedenou obchodní firmu, řidiči pak musejí být držiteli oprávnění řidiče taxislužby, které žadatelům vydá př́islušný dopravní úřad, pokud splňují podmínky spolehlivosti podle § 9 odst. 3 zákona

22 Stanovisko generálního advokáta Marcieje Szpunara ze dne 11. 5. 2017, věc C-434/15. [cit. 16. 5. 2017] Dostupné z: http://eur-lex.europa.eu/legal-content/CS/TXT/?qid= 1494943061735\&uri = CELEX:62015CC0434 
o silniční dopravě a být v základním pracovněprávním vztahu ke společnosti provozující taxislužbu.

Tím, že společnost Uber neplní povinnosti kladené na ní zákonem, získává výhodu oproti ostatním taxislužbám, které tyto povinnosti plní. Společnost Uber pak nepochybně jedná $\mathrm{v}$ hospodářském styku a jde také o jednání, které je způsobilé zpo̊sobit ostatním soutěžitelům újmu. Zákazníci často volí místo klasických taxislužeb právě společnost Uber, a proto ostatním taxislužbám vzniká újma v podobě ušlého zisku. Jednání společnosti Uber naplňuje i poslední podmínku generální klauzule nekalé soutěže, a to že jedná v rozporu s dobrými mravy soutěže. Porušování předpisů veřejného práva za účelem získání soutěžní výhody, je totiž jednou ze soudcovských nekalosoutěžních podstat, kterou jak vyplývá z výše uvedeného společnost Uber naplňuje. ${ }^{23}$

\section{ZÁVĚR}

V úvodu článku bylo vysvětleno, jakým způsobem funguje služba společnosti Uber, v další části byla rozebrána stanoviska generálního advokáta při Soudním dvoru EU a vysvětleno, proč se domnívá, že dopravu zprostředkovanou pomocí mobilní aplikace společnosti Uber, provozuje společnost Uber, a ne jednotliví řidiči. V poslední části článku pak byla popsána dostupná judikatura českých soudů k této problematice a poukázáno na rozpory $\mathrm{v}$ rozhodování jednotlivých soudů a rozebrána česká právní úprava dopadající na společnost Uber. Na základě české právní úpravy a stanoviska generálního advokáta při Soudním dvoru EU, pak bylo vysvětleno, že společnost Uber s největší pravděpodobností provozuje taxislužbu a také rozebrány důvody, proč se dopouští nekalé soutěže.

Toto dílo lze užít $v$ souladu s licenčními podmínkami Creative Commons BY-SA 4.0 International (http://creativecommons.org/licenses/by-sa/4.0/legalcode).

${ }^{23}$ ŠVESTKA, Jiří. DVOŘÁK, Jan. FIALA, Josef. HRÁDEK, Jiří. VOJTEK, Petr. HAJN, Petr. a kol. Občanský zákoník Komentáŕ Svazek VI. Praha: Wolters Kluwer, a. s., 2014, 1170 s. ISBN 978-80-7478-369-2. 